ENDOTOXINs (lipopolysaccharides, LPS) are agents of pathogenicity of Gram-negative bacteria, implicated in the development of Gram-negative shock. Endotoxin reacts with lipopolysaccharide-sensitive cells producing endogenous mediators such as tumour necrosis factor alpha (TNF $\alpha$ ). Macrophages are cells mediating the toxic activities of LPS and TNF $\alpha$ is the primary mediator of the lethal action of endotoxin. This review article discusses the various mechanisms by which endotoxin hypersensitivity in bacteria-sensitized animals develops. The paper concludes with a discussion on the possible protective effect of carnitine congeners against the lethal action of LPS.

\section{Bacterial endotoxins: biological properties and mechanisms of action}

\author{
C. Galanos ${ }^{\mathrm{CA}}$ and M. A. Freudenberg
}

Max-Planck-Institut für Immunbiologie 7800

Freiburg, Stübeweg 51, Germany

${ }^{\mathrm{CA}}$ Corresponding Author
Key words: Bacterial endotoxins, Carnitine congeners, Lipopolysaccharide (LPS), Tumour necrosis factor alpha $(\mathrm{TNF} \alpha)$

\section{Introduction}

Endotoxins are constituents of the outer membrane of Gram-negative bacteria. Isolated endotoxin administered into experimental animals elicits a large spectrum of biological activities which are also manifested during Gram-negative septic shock.

Endotoxins are lipopolysaccharides (LPS). In Enterobacteriaceae and in many cases of other Gram-negative bacteria, LPS are found to consist of three covalently linked regions, the lipid $\mathrm{A}$, the core oligosaccharide and the $\mathrm{O}$-specific polysaccharide. The structure and composition of the O-polysaccharide is highly variable among Gramnegative bacteria, determining the serological specificity of the parent bacterial strain. The core oligosaccharide is less variable in its structure and composition, a given core structure being common to large groups of bacteria. Lipid A is structurally the least variable part of the LPS molecule, exhibiting a similar structure and composition among many Gram-negative bacteria (for reviews see References 1-3). All three parts of the LPS molecule are immunogenic, eliciting the formation of antibodies interacting specifically with distinct epitopes in the respective region. The biological activity of LPS resides solely in the lipid A, the polysaccharide being devoid of toxic activity. ${ }^{2}$ Table 1 summarizes the large spectrum of biological activities that were found to be expressed by purified LPS or isolated free lipid A. As seen from the table the activities of endotoxin are not always harmful but some of these, such as induction of tumour necrosis and adjuvant activity, can be beneficial to the host.

The biological activities of LPS are not direct effects of the LPS molecule but are induced indirectly by endogenous mediators that are produced following interaction of endotoxin with

Table 1. Biological activities of lipopolysaccharides and free lipid A

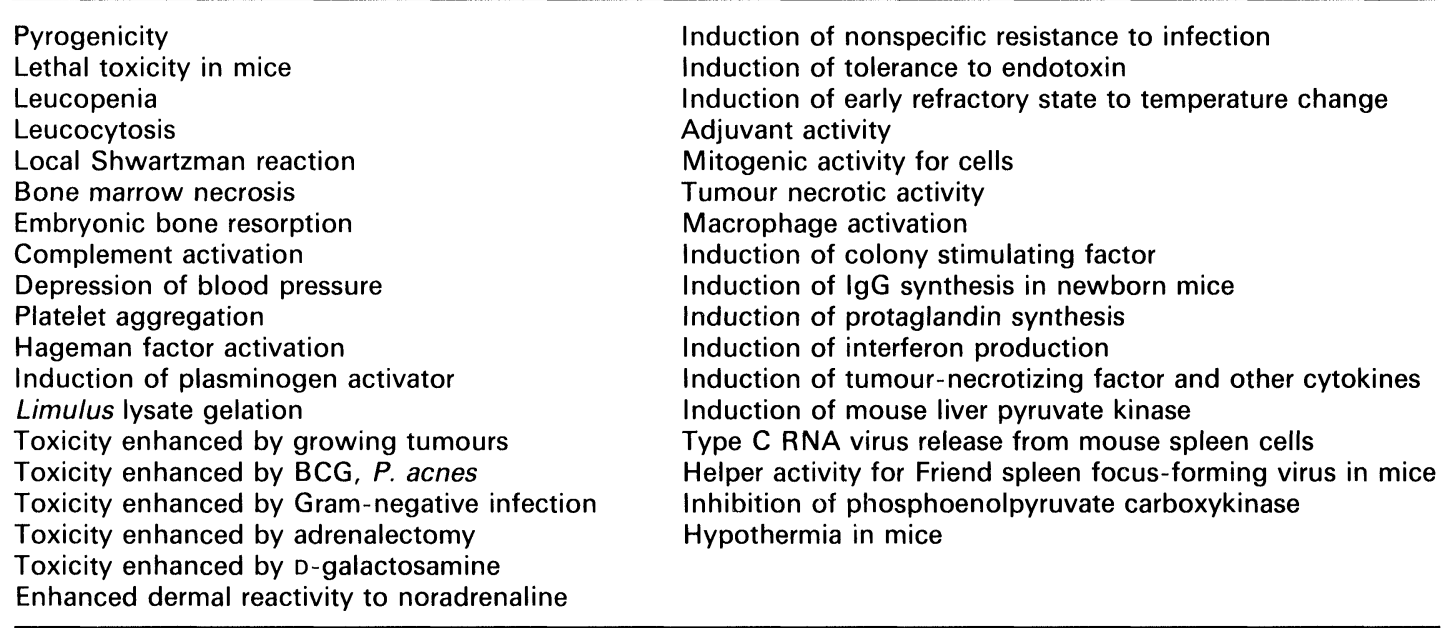


LPS-sensitive cells. Macrophages are cells mediating the toxic activities of $\mathrm{LPS}^{4-6}$ and tumour necrosis factor alpha $(T N F \alpha)$ is a primary mediator of the lethal action of endotoxin. ${ }^{7-10}$

The activity of endotoxin may be influenced (enhanced or suppressed) by a number of plasma proteins of the host, which are capable of binding LPS. These include high and low density lipoproteins (HDL and LDL), ${ }^{11-14}$ LPS-binding protein $(\mathrm{LBP})^{1 \mathrm{~b}}$ and, in addition, specific antibodies directed against the LPS serotype in question and which may be present in the individual host. In the case of endotoxin shock resulting from infection, the toxic activity of the LPS released from the infecting micro-organism may be influenced additionally by bacterial proteins (e.g. Omp A) with which the released LPS may be associated. ${ }^{16}$

Sensitivity to endotoxin is genetically determined, rabbits, swine and humans being highly sensitive; while mice, rats or guinea-pigs are, in comparison, much less sensitive. Mice, depending on strain, usually succumb to the lethal activity of $200-400 \mu \mathrm{g}$ of LPS. Endotoxin-resistant strains of mice have been identified which are insensitive to all LPS effects. ${ }^{17,18}$ These are usually referred to as LPS nonresponders and are designated as $1 \mathrm{ps}^{\mathrm{d}}$, in contrast to mice with normal sensitivity (LPS responder) which are designated as $\mathrm{lps}^{\mathrm{n}}$. The high resistance of $1 p s^{\mathrm{d}}$ mice is due to a genetic defect in the LPS gene locus present on chromosome $4 .{ }^{18}$

\section{Endotoxin hypersensitivity}

Although sensitivity to endotoxin is genetically determined it has been known for many years that the sensitivity of normal healthy animals may be considerably increased under different experimental conditions. The most important of these are listed in Table 2. Thus treatment of experimental animals with hepatotoxic agents such as D-galactosamine will increase their sensitivity to the lethal effects of endotoxin more than 100000 -fold. A significant degree of sensitization may also be achieved following treatment of mice with muramyl dipeptide (MDP), a partial structure of peptidoglycan. Further, adrenalectomy hypophysectomy or exposure to a hyperthermic environment will all enhance considerably the sensitivity to endotoxin. ${ }^{19}$

The sensitivity of mice to endotoxin was also found to be increased by a number of growing tumours. Thus Lewis lung carcinoma, and the EMT6 sarcoma growing in C57BL/6 and BALB/C mice, respectively, were shown to increase considerably the endotoxin sensitivity of the animals ${ }^{20}$ (Table 3).

Sensitization to endotoxin also proceeds following treatment with live (infection) or killed bacteria. ${ }^{21,22}$ Both Gram-positive ${ }^{23}$ and Gram-
Table 2. Induction of hypersensitivity to endotoxin treatment

\begin{tabular}{|c|c|}
\hline $\begin{array}{l}\text { Condition which increases } \\
\text { endotoxin hypersensitivity }\end{array}$ & Sensitization factor \\
\hline \multicolumn{2}{|l|}{ Microbial infections } \\
\hline \multicolumn{2}{|l|}{ Gram-negative } \\
\hline \multicolumn{2}{|l|}{ Salmonella } \\
\hline \multicolumn{2}{|l|}{ E. Coli } \\
\hline \multicolumn{2}{|l|}{ Klebsiella } \\
\hline Coxiella burnetii & $100->1000$ \\
\hline \multicolumn{2}{|l|}{ Gram-positive } \\
\hline \multicolumn{2}{|l|}{$\begin{array}{l}\text { Propionibacterium acnes } \\
\text { BCG }\end{array}$} \\
\hline \multicolumn{2}{|l|}{ Bacterial products } \\
\hline Proteins & 50 \\
\hline MDP & 100 \\
\hline \multicolumn{2}{|l|}{ Parasitic infections } \\
\hline Malaria (B. chabaudi chabaudi) & $>100$ \\
\hline \multicolumn{2}{|l|}{ Growing tumours } \\
\hline Lewis lung carcinoma & $>10000$ \\
\hline EMT6 sarcoma & 200 \\
\hline \multicolumn{2}{|l|}{ Hepatotoxic agents } \\
\hline D-galactosamine & 100000 \\
\hline$\alpha$-amanitine & $>1000$ \\
\hline \multicolumn{2}{|l|}{ Other agents } \\
\hline Carbon tetrachloride & $>1000$ \\
\hline Lead acetate & $>1000$ \\
\hline Actinomycin-D & $>10000$ \\
\hline \multicolumn{2}{|l|}{ Hyperthermia } \\
\hline Environmental temperature $30-33^{\circ} \mathrm{C}$ & $>1000$ \\
\hline \multicolumn{2}{|l|}{ Cortisone deficiency } \\
\hline Adrenalectomy & $>1000$ \\
\hline Hypophysectomy & $>1000$ \\
\hline
\end{tabular}

Table 3. Hypersensitivity of LLC and EMT6 tumour bearing mice to LPS or recombinant TNF

\begin{tabular}{lcc}
\hline & \multicolumn{2}{c}{$\mathrm{LD}_{50}(\mu \mathrm{g} / \mathrm{mouse})$} \\
\cline { 2 - 3 } Mice & LPS & LPS \\
\hline Normal C57BL6 & 400 & 300 \\
$\begin{array}{l}\text { C57BL with carcinoma } \\
\text { (15 day tumour) }\end{array}$ & 0.1 & 0.01 \\
Normal Balb/c & 300 & 300 \\
$\begin{array}{l}\text { Balb/c with sarcoma } \\
\text { (15 day tumour) }\end{array}$ & 2 & 4 \\
\hline
\end{tabular}

Female $\mathrm{C} 57 \mathrm{BL} / 6$ and Balb/c mice were inoculated respectively with $3 \mathrm{LL}$ cells intramuscularly or EMT6 cells subcutaneously. Fifteen days later the animals were challenged intraperitoneally with increasing doses of recombinant TNF or Salmonella a. equi LPS. Each group was formed of six animals receiving increasing doses of the test compound. The mortality was recorded during $48 \mathrm{~h}$.

negative micro-organisms were shown to increase the susceptibility of mice to the lethal activity of endotoxin. Sensitization by bacteria is of special interest and is dealt with in more detail in the following section.

\section{Bacteria-induced hypersensitivity to endotoxin}

For the induction of hypersensitivity to LPS by bacteria both live or killed micro-organisms may be 


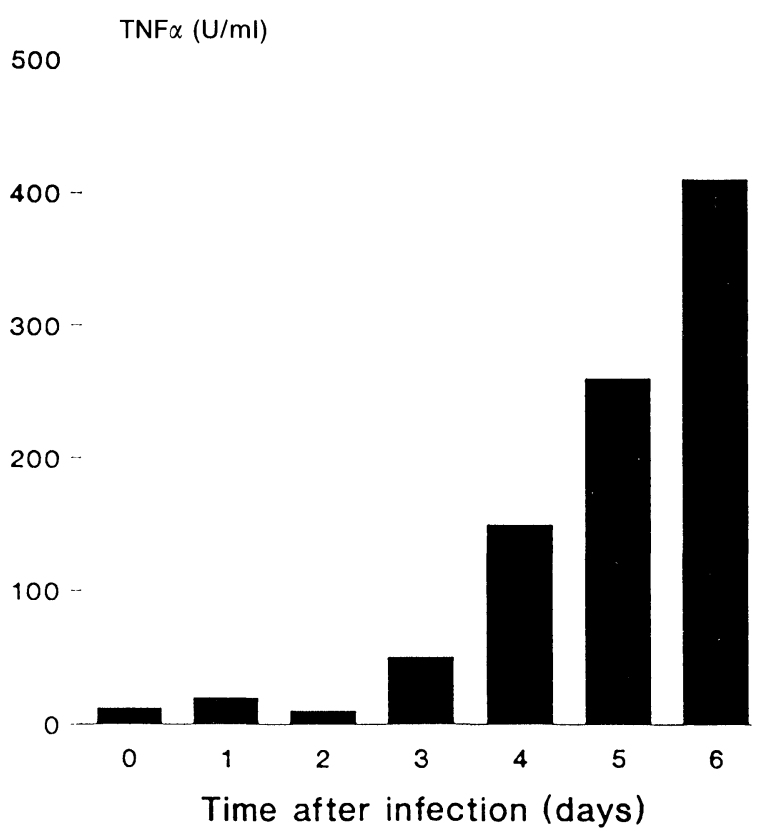

FIG. 1. Enhanced production of TNF $\alpha$ by LPS in $\mathrm{C} 3 \mathrm{H} / \mathrm{HeN}$ mice infected with $S$. Typhimurium. Mice were infected with 50 CFU $S$. typhimurium and challenged with $10 \mu \mathrm{g}$ LPS. Plasma was collected $60 \mathrm{~min}$ after LPS administration.

used. Considerable changes in sensitivity of C57BL/6 mice to the lethal activity of LPS following infection with a lethal inoculum of Salmonella typhimurium have been demonstrated. ${ }^{24}$ Thus, before infection, a dose of over $200 \mu \mathrm{g}$ endotoxin was required to kill the animals. After infection, sensitivity increased daily in an almost logarithmic pattern and by day 5 after infection the lethal dose of endotoxin was less than $1 \mu \mathrm{g}$. $^{24}$

Sensitization to LPS may be also achieved by sub-lethal infection as shown in Fig. 1.22 Mice $(\mathrm{C} 3 \mathrm{H} /$ Tif), infected with a sublethal inoculum of $S$. thyphimurium exhibit enhanced sensitivity to endotoxin. Sensitization becomes evident on day 2 after infection, reaches a maximum on days 7 to 8 and decreases again reaching normal levels several weeks later. Fig. 1 also shows that sensitization to LPS by sublethal infection is at the same time a sensitization to $\mathrm{TNF} \alpha$.

\section{Mechanisms of endotoxin hypersensitivity induced by bacteria}

The property of bacteria to enhance endotoxin sensitivity is not confined to $S$. typhimurium, but is a general phenomenon observed with different live or killed Gram-negative and Gram-positive bacteria. An example of this is shown in Table 4.

Mice made hypersensitive to the lethal effects of LPS by bacteria are found, on LPS challenge, to produce considerably more TNF $\alpha$ than do normal animals. ${ }^{25}$ This is shown in Table 5 where it can be seen that treatment of mice with Propionibacterium acnes or S. typhimurium leads, on LPS challenge, to
Table 4. Sensitivity of mice pretreated with different bacteria to the lethal effects of LPS

\begin{tabular}{lcc}
\hline Pre-treatment & \multicolumn{2}{c}{ Approx. $\mathrm{LD}_{50}(\mu \mathrm{g}$ LPS $)$} \\
\cline { 2 - 3 } & \multicolumn{2}{c}{ Mice } \\
& $\mathrm{HeN}$ & $\mathrm{Sn}$ \\
\hline none & 400 & 100 \\
$P$. acnes & 0.2 & 0.1 \\
C. burnetii & 2 & 0.5 \\
S. typhimurium & 3 & 3 \\
\hline
\end{tabular}

Table 5. Enhanced production of TNF $\alpha$ by LPS in C57BL/10 ScSn mice treated with bacteria

Treatment

$(\mathrm{ng} / \mathrm{ml})$

\begin{tabular}{lcc}
\hline none & none & n.d. \\
& 10 & 2.1 \\
$P$. acnes & none & n.d. \\
& 10 & 3000 \\
S. typhimurium & none & n.d. \\
& 10 & 454 \\
\hline
\end{tabular}

Mice were treated with $P$. acnes $(500 \mu \mathrm{g}, 7$ days before challenge) I.V. or $S$. typhimurium (50 CFU, 3 days before challenge) i.p., and challenged with LPS i.v. Serum for TNF $\alpha$ assay was collected $1 \mathrm{~h}$ after challenge. TNF $\alpha$ was measured by the 929 cell cytotoxicity assay with murine rTNF $\alpha$ as standard. n.d. $=$ not detectable

a 1500 - and 200-fold increase in the amount of TNF $\alpha$ produced, respectively (Fig. 2).

Since $T N F \alpha$ is a primary mediator of the lethal activity of LPS, the overproduction of $\mathrm{TNF} \alpha$ by

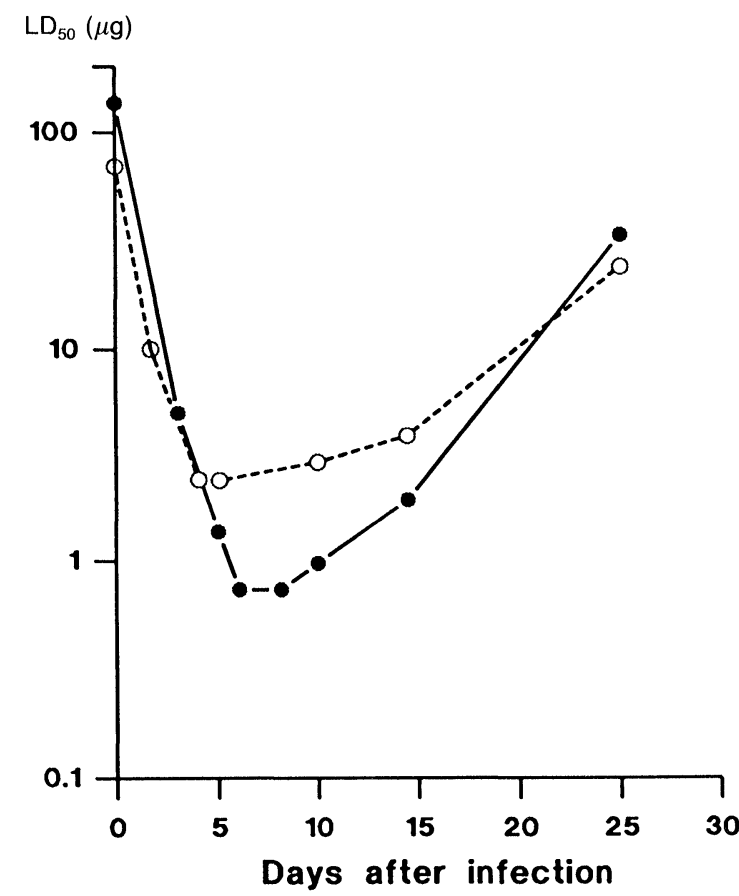

FIG. 2. Sensitization of mice to the lethal activity of LPS and HrTNF $\alpha$ by sub-lethal infection with $S$. typhimurium. Mice $(\mathrm{C} 3 \mathrm{H} / \mathrm{Tif})$ were infected with $2 \times 10^{4} \mathrm{CFU}$ of $S$. typhimurium and on different days thereafter groups were challenged with different amounts of LPS and the $L_{50}$ values were calculated. LPS, $\bigcirc \mathrm{HrTNF} \alpha$. 
Table 6. Effect of treatment with bacteria on the sensitivity of mice to the lethal activity of human rTNF $\alpha$

\begin{tabular}{lrc}
\hline Treatment & & $\begin{array}{c}\text { Lethality } \\
\%\end{array}$ \\
\hline none & 75 & 0 \\
& 225 & 50 \\
$P$. acnes & 1 & 0 \\
& 5 & 20 \\
S. typhimurium & 10 & 100 \\
& 1 & 10 \\
& 10 & 100 \\
\hline
\end{tabular}

C57BL/10 ScSn mice were treated with heat killed $P$. acnes (500 $\mu$ g i.v., 7 days before challenge), or infected with $S$. typhimurium (50 CFU i.p., 3 days before challenge). Human $\mathrm{TNF} \alpha$ was administered i.v.

LPS, in bacteria sensitized animals, would alone explain hypersensitivity. However, the high endotoxin sensitivity of bacteria treated mice is not due only to an overproduction of TNF $\alpha$. Mice sensitized to the lethal effects of LPS by bacteria are also found to be hypersensitive to the lethal activity of TNF $\alpha$. This is shown in Table 6. Therefore the hypersensitivity to the lethal effects of endotoxin seen in bacteria sensitized mice is based on (a) an overproduction of $\mathrm{TNF} \alpha$, and (b) a higher sensitivity to the lethal effects of TNF $\alpha$.

The induction of hypersensitivity by Gramnegative bacteria is of special interest since these micro-organisms also produce endotoxin. The present results make it evident that Gram-negative bacteria not only produce endotoxin but also sensitize the infected organism to its toxic action, and therefore enable a better understanding of the hazardous consequences of Gram-negative infections.

\section{Mechanism of the sensitization to endotoxin by bacteria}

Interferon gamma, a mediator of the bacteria-induced sensitization: Very recently a breakthrough in the understanding of the mechanism by which bacteria sensitize the organism to endotoxin was achieved. When mice are infected with live, or treated with killed, Gram-negative or Gram-positive bacteria, they are found to contain in their serum significant amounts of interferon gamma $(\mathrm{IFN} \gamma){ }^{25}$ The production of IFN $\gamma$ following treatment with bacteria is true for all strains of mice that are sensitive to endotoxin. The observation was made however that a similar treatment of LPS resistant $\left(\mathrm{lps}^{\mathrm{d}}\right)$ strains of mice (see introduction) with bacteria does not lead to IFN $\gamma$ production. ${ }^{26}$ This observation suggested that the inability of $1 \mathrm{ps}^{\mathrm{d}}$ mice to be sensitized by bacteria might be due to their inability to produce IFN $\gamma$. This possibility was investigated closely, and evidence could be obtained that IFN $\gamma$ is the mediator of sensitization of animals treated with bacteria to the lethal activity of LPS. ${ }^{25}$ Thus, administration of anti-IFN $\gamma$ monoclonal antibodies to mice pre-treated with bacteria inhibited the overproduction of TNF $\alpha$ (Fig. 3) and abolished the development of sensitization to the lethal activity of LPS (Table 7).

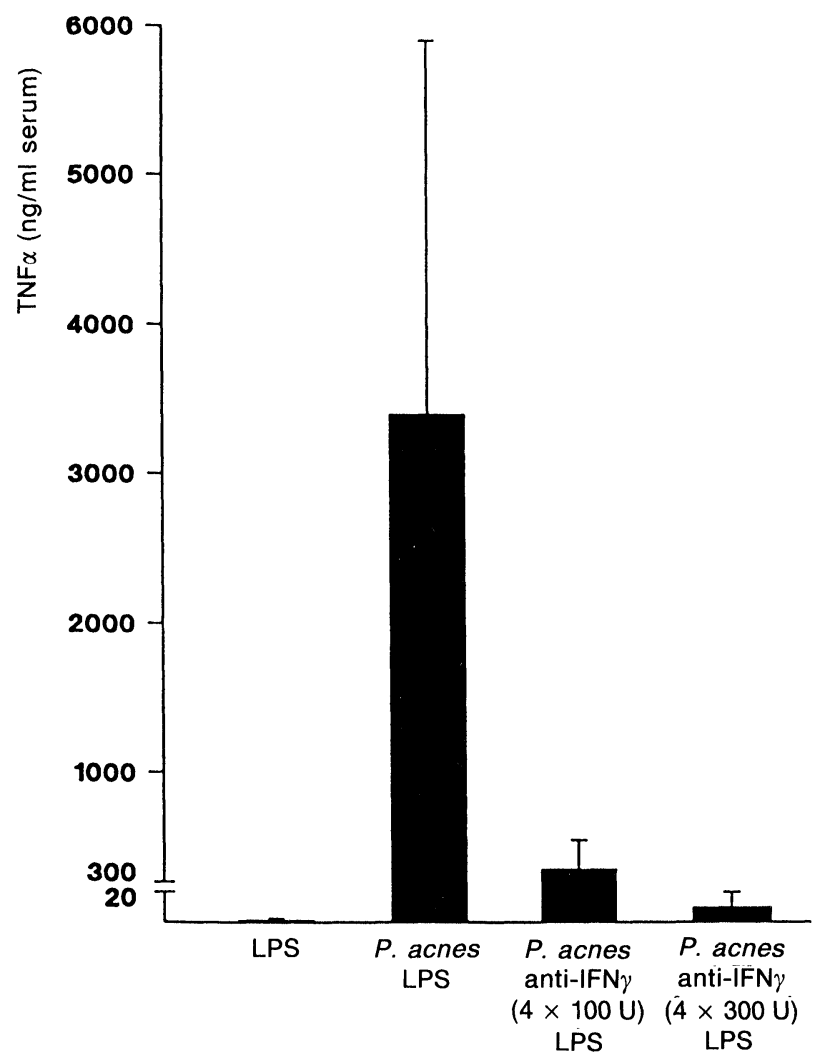

FIG. 3. Effect of anti-IFN $\gamma$ on P. acnes induced sensitization to LPS. TNF $\alpha$ production.

Table 7. Effect of IFN $\gamma$ antibodies on the $P$. acnes induced sensitization to LPS lethality

\begin{tabular}{clcc}
\hline & \multicolumn{3}{c}{ Lethality (dead/total) } \\
\cline { 2 - 4 } LPS $(\mu \mathrm{g})$ & Controls & $P$. acnes + IgG & $P$. acnes + mAb \\
\hline 100 & $5 / 5$ & - & - \\
75 & $1 / 5$ & - & - \\
50 & $0 / 10$ & - & $6 / 10$ \\
25 & - & - & $0 / 5$ \\
1 & - & $5 / 5$ & - \\
0.1 & - & $2 / 5$ & - \\
0.01 & - & $0 / 5$ & - \\
\hline
\end{tabular}

C57BL/10 ScSN mice received $500 \mu \mathrm{g} P$. acnes, i.v. Thereafter, one group of mice received $4 \times 300 \mu \mathrm{g}(300 \mathrm{U})$ anti-IFN $\gamma$, a second group $4 \times 300 \mu \mathrm{g}$ control IgG i.p. on days $0,2,4$ and 6 after $P$. acnes treatment. Seven days after $P$. acnes, all mice were challenged with LPS, i.v. Normal, untreated Sn mice, injected with LPS only served as controls. Lethality was scored up to $72 \mathrm{~h}$ after LPS injection. 


\section{Protection against endotoxin shock}

Even since LPS was recognized as the main toxic component of Gram-negative bacteria, research groups all over the world have been searching for effective ways for treating and preventing endotoxin shock. One approach investigated extensively has been the use of antibodies to different regions of the LPS molecule. Of special interest have been antibodies directed towards parts of the LPS molecule that are common among clinically relevant Gram-negative micro-organisms. Other approaches include the use of cortisone, antibodies to the LPS receptor and the use of LPS receptor antagonists.

Recently, the authors investigated whether carnitine congeners might exhibit a protective effect against the lethal action of LPS. In these experiments both L-carnitine and acetyl-L-carnitine were used. The lethality models used include mice sensitized to the lethal activity of LPS by D-GalN and by Propionibacterium acnes, as well as normal mice. In approximately $50 \%$ of the experiments a protection was seen in both sensitization models. Even where no protection was found in terms of survival, a prolongation of survival was always evident. The following tables show the results of typical experiments in which protection was found.

Table 8 shows that administration of $5 \mathrm{mg}$ acetyl-I-carnitine/mouse, $30 \mathrm{~min}$ prior to a lethal challenge with LPS and D-GalN afforded complete protection to the animals. A similar protection was seen when instead of LPS, recombinant hTNF $\alpha$ and D-GalN were used for challenge (Table 9). An investigation of the time of acetyl-L-carnitine administration that yields optimal protection

Table 8. Effect of acetyl-L-carnitine on the lethal activity of LPS in $\mathrm{D}$-GalN sensitized mice

\begin{tabular}{lccc}
\hline $\begin{array}{l}\text { Ac-L-carnitine } \\
(\mathrm{mg})\end{array}$ & $\begin{array}{c}\text { D-GalN } \\
(\mathrm{mg})\end{array}$ & $\begin{array}{c}\text { LPS } \\
(\mu \mathrm{g})\end{array}$ & $\begin{array}{c}\text { Lethality } \\
\text { dead/total }\end{array}$ \\
\hline 5 & 20 & 0.002 & $0 / 4$ \\
- & 20 & 0.002 & $4 / 4$ \\
\hline
\end{tabular}

Mice were C57BL/6 strain; LPS was from $S$. abortus equi; all injections were administered i.v.; acetyl-L-carnitine was administered $30 \mathrm{~min}$ prior to LPS/D-GaIN

Table 9. Effect of acetyl-L-carnitine on the lethal activity of TNF $\alpha$ in $\mathrm{D}-$ GalN sensitized mice

\begin{tabular}{lccc}
\hline $\begin{array}{l}\text { Ac-L-carnitine } \\
(\mathrm{mg})\end{array}$ & $\begin{array}{c}\text { D-GalN } \\
(\mathrm{mg})\end{array}$ & $\begin{array}{c}\text { TNF } \\
(\mu \mathrm{g})\end{array}$ & $\begin{array}{c}\text { Lethality } \\
\text { dead/total }\end{array}$ \\
\hline 5 & 20 & 1 & $0 / 4$ \\
- & 20 & 1 & $4 / 4$ \\
\hline
\end{tabular}

Mice were C57BL/6 strain; LPS was from $S$. abortus equi; all injections were administered i.v.; acetyl-L-carnitine was administered $30 \mathrm{~min}$ prior to LPS/D-GalN
Table 10. Effect of time of acetyl-L-carnitine injection on the lethal activity of LPS/GalN in mice

\begin{tabular}{ccc}
\hline $\begin{array}{c}\text { Time of Ac-L-carnitine } \\
\text { administration }(\mathrm{h})\end{array}$ & $\begin{array}{c}\text { Time of LPS/GalN } \\
\text { injection }(\mathrm{h})\end{array}$ & $\begin{array}{c}\text { Lethality } \\
\text { deal/total }\end{array}$ \\
\hline-24 & 0 & $1 / 4$ \\
-4 & 0 & $2 / 4$ \\
-2 & 0 & $0 / 4$ \\
0 & 0 & $1 / 4$ \\
1 & 0 & $2 / 4$ \\
4 & 0 & $4 / 4$ \\
\hline
\end{tabular}

$\mathrm{C} 57 \mathrm{BL} / 6$ mice received acetyl-L-carnitine $(5 \mathrm{mg})$ at the times indicated, and D-GaIN (20 mg) with LPS $(0.002 \mu \mathrm{g})$ at $0 \mathrm{~h}$.

Table 11. Effect of acetyl-L-carnitine on the lethal activity of LPS in $P$. acnes sensitized mice

\begin{tabular}{ccc}
\hline $\begin{array}{c}\text { Ac-L-carnitine } \\
(\mathrm{mg})\end{array}$ & $\begin{array}{c}\text { LPS } \\
(\mathrm{mg})\end{array}$ & $\begin{array}{c}\text { Lethality } \\
\text { dead/total }\end{array}$ \\
\hline 10 & 0.2 & $1 / 4$ \\
5 & 0.2 & $0 / 4$ \\
2.5 & 0.2 & $0 / 4$ \\
1.25 & 0.2 & $3 / 4$ \\
- & 0.2 & $4 / 4$ \\
\hline
\end{tabular}

(C57BL/6) mice were treated with $500 \mu \mathrm{g}$ killed Propionibacterium acnes i.v. 7 days before challenge. Acetyl-L-carnitine was administered i.p. $1 \mathrm{~h}$ before LPS (i.v.).

revealed that the drug afforded maximum protection when administered 1-2 $\mathrm{h}$ before LPS/GalN challenge (Table 10). A protection by acetyl-Lcarnitine was also seen in mice sensitized by $P$. acnes and challenged with LPS (Table 11). More experiments are being carried out in order to confirm the protection seen so far and to make a preliminary identification of the possible mechanisms involved.

\section{References}

1. Lüderitz O, Galanos C, Lehman V, Mayer H, Rietschel E Th, Weckesser J Chemical structure and biological activities of lipid A's from various bacterial families. Naturwissenschaften 1978; 65: 579-585.

2. Galanos C, Lüderitz O, Rietschel E Th, Westphal O. Newer aspects of the chemistry and biology of bacterial lipopolysaccharides, with special reference to their lipid A component. In: Goodwin TW, ed. International Reviens of Biochemistry, Vol. 14, Biochemistry of Lipids II, Baltimore: University Park Press, 239-335.

3. Rietschel $\mathrm{E}$ Th, ed. Handbook of Endotoxin, Vol. 1, Chemistry of Endotoxin Elsevier, 1984

4. Michalek SM, Moore RN, McGhee JR, Rosenstreich DL, Mergenhagen SE. The primary role of lymphoreticular cells in the mediation of host responses to bacterial endotoxin. J Infect Dis 1980; 141: 55-63.

5. Rosenstreich DL, Vogel SN. Central role of macrophages in the host response to endotoxin. In: Schlesinger D, ed. Microbiology-1980. Washington, D.C. American Society for Microbiology, 1980; 11-15.

6. Freudenberg MA, Keppler D, Galanos C. Requirement for lipopolysaccharide-responsive macrophages in galactosamine-induced sensitization to endotoxin. Infect Immun 1986; 51: 891-895.

7. Beutler B, Milsark JW, Cerami AC. Passive immunization agains cachectin/tumor necrosis factor protects mice from lethal effect of endotoxin. Science 1985; 229: 869-871.

8. Lehmann V, Freudenberg MA, Galanos C. Lethal toxicity of lipopolysaccharide and tumour necrosis factor in normal and D-galactosamine-treated mice. $J$ Exp Med 1987; 165: 657-663.

9. Galanos C, Freudenberg MA, Coumbos A, Matsuura M, Lehmann V, Bartoleyns $J$. Induction of lethality and tolerance by endotoxin are mediated by macrophages through tumour necrosis factor. In: Bonavida B, Gifford GE, Kirchner H, Old LJ, eds. Tumour Necrosis Factor/Cachectin and Related Cytokines. Basel: S. Karger, 1988: 114-127. 
10. Freudenberg MA, Galanos C. Tumour necrosis factor alpha mediates lethal activity of killed gram-negative and gram-positive bacteria in Dgalactosamine-treated mice. Infect Immun 1991; 59: $2110-2115$

11. Skarnes RC. In: Berry LJ, ed. Cellular Biology of Hndotoxin, Vol. 3. Amsterdam, New York, Oxford: Elsevier, 1985; 56.

12. Ulevitch RJ, Johnston AR, Weinstein DB. New function for high density lipoproteins. Their participation in intravascular reactions of bacterial lipopolysaccharides. J Clin Invest 1979; 64: 1516-1524.

13. Freudenberg MA, Bøg-Hansen TC, Back U, Jirillo E, Galanos C Interaction of lipopolysaccharides with plasma high density lipoprotein in rats. In: Eaker D, Wadstrom 'T, eds. Natural toxins. New York: Pergamon Press, 1980.

14. Munford RS, Hall CL, Lipton JM, Dietschy JM. Biological activity, lipoprotein-binding behaviour, and in vivo disposition of extracted and active forms of Salmonella typhimurium lipopolysaccharides. J Clin Invest 1982; 70 : 877-888.

15. Schuhmann RR, Leong SR, Flaggs GW, Gray PW, Wright SD, Mathison JC. Structure and function of lipopolysaccharide-binding protein. Science 1990; 249: 1429-1431.

16. Freudenberg MA, Meier-Dieter U, Staehelin T, Galanos C. Analysis of LPS released from Salmonella abortus equi in human serum. Microb Pathogen 1991 , 10: $93-104$.

17. Sultzer BM, Goodman GW. Characteristics of endotoxin-resistant low-responder mice. In: Schlesinger D, ed. Microbiology-1977, Washington DC: American Society for Microbiology, 1977: 304-309.

18. Coutinho A, Meo T. Genetic basis for unresponsiveness to lipopolysaccharide in C57BI./10Cr mice. Immunogenetics 1978; 7: 17-24
19. Galanos C, Freudenberg MA, Katschinski T, Salomão R, Mossmann $\mathrm{H}$, Kumazawa $\mathrm{Y}$. Tumour necrosis factor and host response to endotoxin. In Ryan J, Morrison DC, eds. Bacterial endotoxin lipopolysaccharides, Vol. 2. Immunopharmacology and pathophysiology. Boca-Raton, FL: CRC Press Inc., 1992; 75-104.

20. Bartoleyns J, Freudenberg MA, Galanos C. Growing tumours induce hypersensitivity to endotoxin and tumor necrosis factor. Infect Immun 1987; 55: $2230-2233$.

21. Galanos C, Freudenberg MA, Matsuura M. Mechanisms of the lethal action of endotoxin hypersensitivity. In: Friedman $\mathrm{H}$, Klein TW, Nakano M, Nowotny A, eds. Endotoxin: Advances in experimental medicine and biology, Vol. 256. New York: Plenum Press, 1990; 603-619.

22. Matsuura M, Galanos C. Induction of hypersensitivity to endotoxin and tumour necrosis factor by sublethal infection with Salmonella typhimurium. Infect Immun 1990; 58: 935-937.

23. Suter E, Ullman GE, Hoffmann RG. Sensitivity of mice to endotoxin after vaccination with BCG (bacillus Calmette-Guérin). Proc Soc Exp Biol Med 1958; 99: 167-169.

24. Galanos C, Freudenberg MA, Krajewska D, Takada H, Georgiev G Bartoleyns J. Hypersensitivity to endotoxin. HOS J Immunol Immunopharmacol 1986; 6(Suppl. 3) : 78-81.

25. Katschinski T, Galanos C, Coumbos A, Freudenberg MA. Gamma interferon mediates Propionibacterium acnes-induced hypersensitivity to lipopolysacchar ide in mice. Infect Immun 1992; 60: 1994-2001.

26. Freudenberg MA, Kumazawa Y, Meding S, Langhorne J, Galanos C. Gamma interferon production in endotoxin-responder and -nonresponder mice during infection. Infect Immun 1991; 59: 3484-3491. 


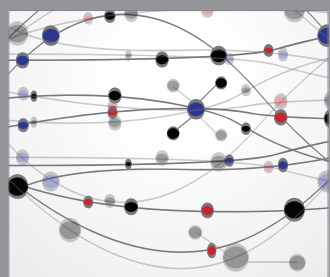

The Scientific World Journal
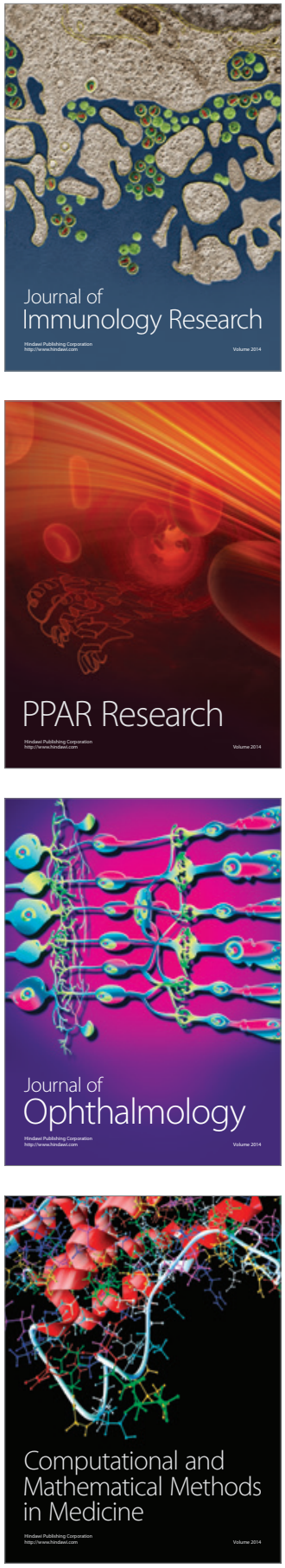

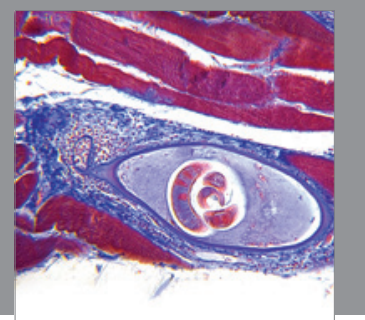

Gastroenterology

Research and Practice
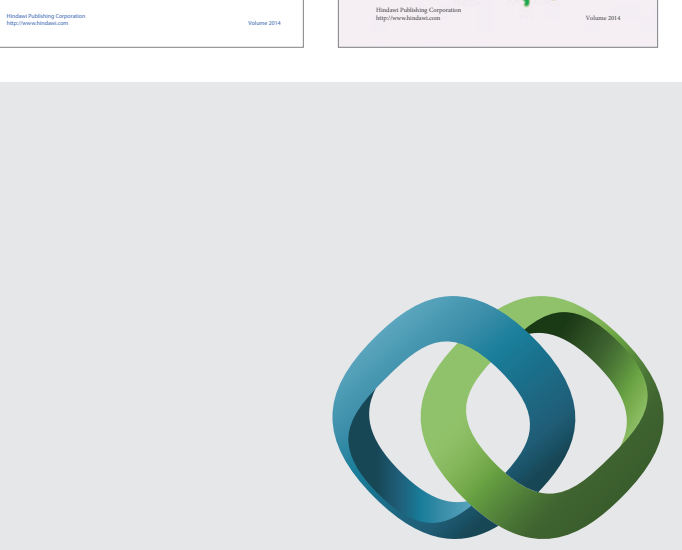

\section{Hindawi}

Submit your manuscripts at

http://www.hindawi.com
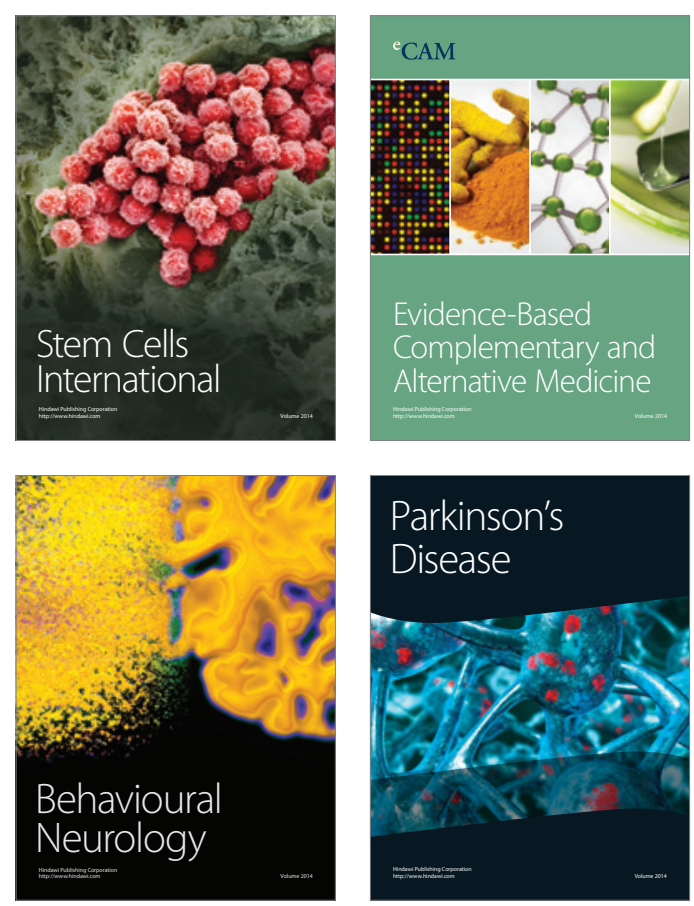

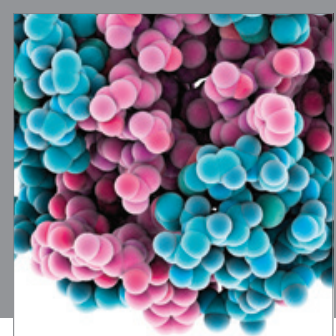

Journal of
Diabetes Research

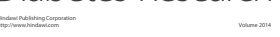

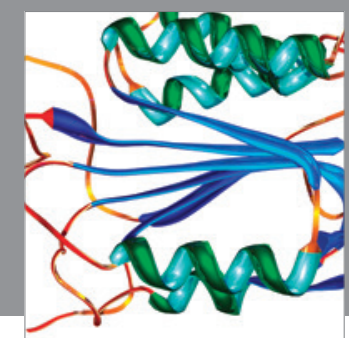

Disease Markers
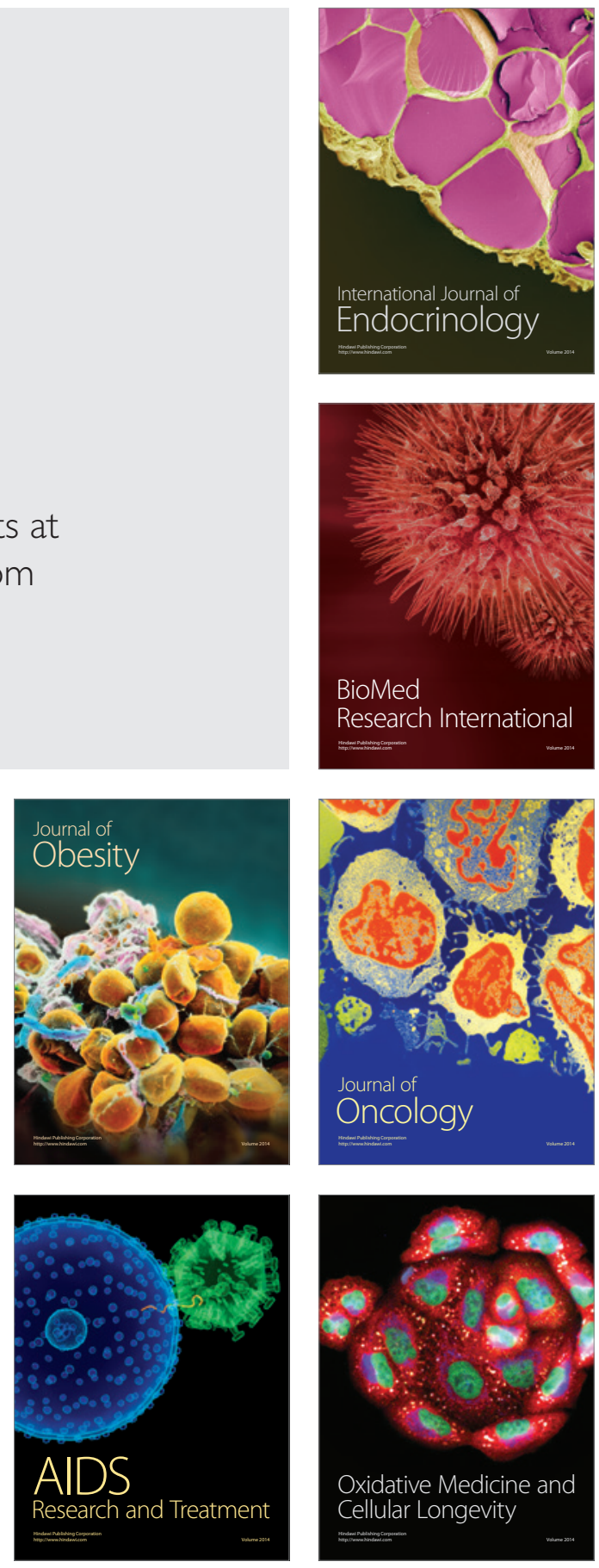